\title{
The Neurobiological Impact of Ghrelin Suppression after Oesophagectomy
}

\author{
Conor F. Murphy ${ }^{1}$ and Carel W. le Roux ${ }^{1,2, *}$ \\ 1 Diabetes Complications Research Centre, Conway Institute, University College Dublin, Dublin 4, Ireland; \\ cmurph1010@gmail.com \\ 2 Gastrosurgical Laboratory, Sahlgrenska Academy, University of Gothenburg, 40530 Gothenburg, Sweden \\ * Correspondence: carel.leroux@ucd.ie; Tel.: +353-86-411-7842
}

Academic Editors: Suzanne L. Dickson and Katalin Prokai-Tatrai

Received: 16 August 2016; Accepted: 19 December 2016; Published: 26 December 2016

\begin{abstract}
Ghrelin, discovered in 1999, is a 28-amino-acid hormone, best recognized as a stimulator of growth hormone secretion, but with pleiotropic functions in the area of energy homeostasis, such as appetite stimulation and energy expenditure regulation. As the intrinsic ligand of the growth hormone secretagogue receptor (GHS-R), ghrelin appears to have a broad array of effects, but its primary role is still an area of debate. Produced mainly from oxyntic glands in the stomach, but with a multitude of extra-metabolic roles, ghrelin is implicated in complex neurobiological processes. Comprehensive studies within the areas of obesity and metabolic surgery have clarified the mechanism of these operations. As a stimulator of growth hormone (GH), and an apparent inducer of positive energy balance, other areas of interest include its impact on carcinogenesis and tumour proliferation and its role in the cancer cachexia syndrome. This has led several authors to study the hormone in the cancer setting. Ghrelin levels are acutely reduced following an oesophagectomy, a primary treatment modality for oesophageal cancer. We sought to investigate the nature of this postoperative ghrelin suppression, and its neurobiological implications.
\end{abstract}

Keywords: ghrelin; ghrelin suppression; GHS-R1A; oesophageal carcinoma; appetite; anticipatory feeding; reward-induced feeding; oesophagectomy

\section{Introduction}

Kojima et al. ascertained, in 1999, that the endogenous ligand for GHS-R1a was ghrelin, a peptide hormone capable of stimulating the anterior pituitary gland to secrete growth hormone [1]. Ghrelin is produced by cells within the gastric fundus, known as Gr-cells. This discrete population of enteroendocrine cells is a subtype of oxyntic or X/A-like cells, and represents approximately $20 \%$ of this cell population [2]. The majority of circulating ghrelin is in the form of desacyl ghrelin, but ghrelin-O-acyl-transferase (GOAT) facilitates the post-translational addition of an acyl side-chain to pro-ghrelin at position 3 of the serine residue-forming acyl ghrelin. Ghrelin octanoylation by GOAT allows it to bind GHS-R1a, and thus is key to its orexigenic and metabolic activity [3]. Other preproghrelin gene-derived peptides include obestatin. The year following its discovery, Tschop et al. demonstrated that ghrelin targeted areas of the brain to assist in the regulation of body weight, glucose metabolism and food intake [4]. Subsequent discoveries have implicated it in a multitude of functional roles executed via diverse but complementary mechanisms, with central and peripheral interactions. The definitive part ghrelin plays in everyday neurobiology is incompletely understood. Research in the area of ghrelin suppression in post-upper gastrointestinal surgery, although limited, has aided in the attempt to answer some questions regarding its role. 


\section{Discussion}

\subsection{Energy Homeostasis}

Ghrelin's role in energy homeostasis appears to be mediated by action upon hypothalamic circuits [5,6]. GHS-R is created in afferent neurons of the vagus, then axonally transported to be expressed mainly in the gastric mucosa [7]. Once bound by ghrelin, an orexigenic effect is stimulated. GHS-R dampens activity within the afferent neuron, signalling to the nucleus tractus solitarius, which transmits the stimulus to neuropeptide Y (NPY)- and agouti-related peptide (AgRP)-containing neurons within the hypothalamus [8,9]. NPY/AgRP-double-knock-out mice are resistant to ghrelin's orexigenic stimulus, and inhibition of this system, both pharmacologically and immunologically, serves to block ghrelin-induced feeding effects, highlighting the importance of this hypothalamic pathway [2]. The arcuate nucleus is an important target for ghrelin when it comes to regulating food intake [10,11], but other hypothalamic regions can also lead to the promotion of positive energy balance when stimulated with ghrelin administration, such as the paraventricular nucleus (PVN) [12,13], the dorsomedial hypothalamus (DMH) [14] and the lateral hypothalamus (LHA) [15]. The hippocampus has been implicated in the behavioural aspect of feeding [16,17], with evidence of widespread expression of GHS-R in hippocampal neurons [18]. Activation of ventral hippocampal neurons by ghrelin increases meal frequency and size in murine models [19]. This effect is potentially mediated via direct communication between ghrelin-activated hippocampal neurons and neurons in the LHA that express orexin, a neuropeptide [20].

Ghrelin was found to have many more effects, both peripherally and centrally, such as energy conservation, by reducing energy expenditure via suppression of brown adipose tissue (BAT) thermogenesis [21-25] and policing glucose metabolism, and by preventing muscular atrophy through promotion of skeletal muscle cell fusion [26,27]. Ghrelin stimulates the secretion of both gastric acid and motilin [28,29], and also enhances vasodilation and cardiac contractility [30-33]. Influencing motility via these peptides may perhaps play a part in its role in anticipatory feeding and in increasing meal size. Although initially thought to be an inert degradation product of acylated ghrelin, there is evidence suggesting that desacyl ghrelin is an active hormone that can both agonise and antagonise acyl ghrelin, as well as having its own receptor [34]. Murine studies have demonstrated that it may have anorexigenic activity via mechanisms such as a reduced gastric emptying rate [35].

\subsection{Hunger Hormone?}

Ghrelin's well-described orexigenic effect on food intake is regulated by sensing the presence of nutrients, and relaying this information to the brain. As such, ghrelin is frequently thought of as the "hunger hormone" [6,36-39], but this is a one-dimensional view of what is clearly a multifunctional hormone. It has also, perhaps more accurately, been described as a meal-anticipatory hormone based on the fact that its levels rise prior to anticipated feeding, independent of energy deprivation levels [38,40], with rapid suppression of circulating levels post-prandially. Furthermore, ghrelin receptor-null mice, under meal entrainment feeding circumstances, do not demonstrate the same response [41]. This association with conditioned appetite and feeding, which appears to be mediated through a neural conversation between the ventral hippocampus and the lateral hypothalamus, may link a number of the demonstrated neurobiological effects of ghrelin, although this area is incompletely understood. Nonetheless, it is intimately linked with hunger levels [37,42], and binds to receptors located within subcortical areas involved in satiety and food intake regulation [9-11,43].

\subsection{Neurobiological Role of Ghrelin}

Both ghrelin and its receptor are widely expressed in multiple regions of the brain [6,44-47], many of which are associated with feeding behaviour [48]. While having a pivotal role in energy homeostasis as an orexigenic hormone, research over the past two decades has also implicated ghrelin in a myriad of neurophysiological functions, such as learning and memory $[19,49,50]$, psychological 
stress, mood, anxiety [51,52], depression [53-55] and addiction [56]. Further central effects include influencing the circadian rhythm [57-59], modulation of anxiety and stress [53,60,61], and stimulating reward-seeking behaviour, as well as the motivation to eat [62-67]. Using functional magnetic resonance imaging (fMRI), Malik et al. demonstrated increased activation in areas such as the amygdala and orbitofrontal cortex during intravenous ghrelin infusion and exposure to pictures of food [68]. At the level of the ventral tegmental area (VTA), but not the nucleus accumbens (NAc), ghrelin increases motivation for food, reflected by an increased lever-pressing behaviour for sucrose pellets in a progressive ratio task [69]. As evidenced by these findings, as well as its discussed hippocampal effects, ghrelin appears to recruit pathways involved in reward-based eating behaviour, as opposed to those associated with energy homeostasis. This extra-homeostatic feeding impulse, in addition to ghrelin's anticipatory feeding role, may represent alternate functions, which, when altered post-operatively, can potentially exhibit abnormal physical and psychological sequelae.

Interestingly, quality of life scores are reduced following oesophagectomy, with functional scores in areas such as emotional issues and anxiety lower than average [70]. Overall, the impact of prolonged ghrelin suppression on these vital processes is not well known. Whether it may be partly accountable for post-operative neuropsychological symptoms is an area yet to be explored. As a natural stimulator of growth hormone (GH), and also GH-releasing hormone and somatostatin release, ghrelin acts as a communicator between the pituitary gland, and the gastrointestinal tract. This signaling pathway facilitates the regulation of anabolism and substrate use, matching them to available energy resources. Ghrelin can stimulate more efficient energy usage via hypothalamic pathways in times of nutrient deficit, in tandem with its aforementioned suppressive effect on BAT thermogenesis [4]. Disruption of these effects post-operatively may lead to inappropriate regulation of energy expenditure. Overall, its link with appetite, energy homeostasis and energy expenditure has led to extensive research within the areas of obesity and metabolic surgery, as well as the cancer cachexia syndrome.

\subsection{Post-Operative Ghrelin Suppression}

The incidence of oesophageal adenocarcinoma has been rising steadily, correlating with the rise in metabolic disease and obesity [71-73]. In keeping with this, oncological outcomes have improved, in patients treated with curative intent, due to factors such as increased centralisation of surgery, improved staging and peri-operative care and well-structured screening programmes [74]. For patients with locally advanced cancer receiving multimodal therapy, the recent neoadjuvant chemoradiotherapy (CROSS) trial quoted three-year survival and five-year survival rates as $58 \%$ and $47 \%$, respectively [75-77]. With this improved survivorship has come a renewed focus on health-related quality of life post-operatively. Amongst the frequently reported post-operative complications are weight loss, loss of appetite and early satiety. Approximately one in three patients who are disease-free have over 15\% weight loss at three years [78]. Calorie malnutrition is thus a major issue.

Upper gastrointestinal surgery, such as Roux-en-Y gastric bypass (RYGB), also leads to changes in body weight and appetite, and is often associated with a reduction in ghrelin levels [79-82]. Subsequent data, however, show that ghrelin levels frequently return to pre-operative levels within the first year after this surgery in humans [83] and within six weeks after surgery in mice [84], with some studies showing an increase in ghrelin post-RYGB [85]. Additionally, compared to wild-type control mice, in ghrelin-knock-out mice, vertical sleeve gastrectomy is equally efficient in lowering body weight [86], which would suggest a ghrelin-independent effect in this type of bariatric surgery. The mechanism of this ghrelin suppression is an area of much research. One potential factor is supraphysiological increases in post-prandial gut hormones, which arise from the small bowel, as observed in specific post-surgical states [87-89], including bariatric and oesophagogastric cancer surgery. GLP-1 may exhibit this effect via its insulinotropic action, as insulin is a known modulator of plasma ghrelin and was capable of suppressing it by $19 \%-64 \%$ in one study [90]. Although long-term data are not available describing the trend of this phenomenon over time, perhaps this mechanism could account for the relative recovery of ghrelin levels in the longer-term. Doki et al. hypothesized that 
the level of ghrelin circulating after such an operation and the amount of residual stomach may be directly proportional. Indeed, they reported that following oesophagectomy and gastrectomy, ghrelin levels were reduced by approximately $10 \%$ to $50 \%$, respectively, while colectomy did not lead to any change [80]. Furthermore, in a study comparing gastroduodenal (GD) with gastrojejunal (GJ) reconstruction following partial gastrectomy for gastric cancer, ghrelin levels fell dramatically in both groups immediately post-operatively, but at one year the levels in GD patients increased more distinctly. This suggests that the duodenum may have a crucial compensatory ghrelin-producing role [91]. A less explored area of interest is the body mass index-(BMI)-independent change in gut microbiota composition following bariatric surgery [92], given that this "virtual endocrine organ" may influence gut hormone secretion [93].

Miyazaki et al. demonstrated an association between reduced BMI and reduced plasma ghrelin levels at six to 24 months post-oesophagectomy with gastric tube reconstruction, with ghrelin levels falling from $130.8 \pm 13 \mathrm{fmol} / \mathrm{mL}$ pre-operatively to $50.6 \pm 5.9$ and $73.2 \pm 9.7 \mathrm{fmol} / \mathrm{mL}$ at seven days and a mean of 20.1 months (range, six to 23.5 months) post-operatively. However, ghrelin levels returned to pre-operative levels $(146 \pm 44.8 \mathrm{fmol} / \mathrm{mL}$ ) over 36 months (mean 53.4, range 39-80 months) post-operatively in this study, while BMI continued to decrease. The authors concluded that the reason for this medium-term discordance was unclear, likely multi-factorial and would need further investigation. Weight loss and plasma ghrelin have also not been found to correlate perennially in other studies [79,94]. Nevertheless, a phase II randomised trial looking at the clinical effects of a 10-day course of exogenous ghrelin administration post-oesophagectomy commencing on the first day of oral food intake concluded that it improved post-operative oral intake and attenuated weight loss in the acute period, and therefore warranted further evaluation to assess medium- and long-term effects [95]. Furthermore, persistently elevated ghrelin levels were noted in patients with diet-induced weight loss, which often tends to be unsustainable $[82,96]$. Overall, these results could implicate ghrelin as a contributor to the mechanism underlying the weight loss in some cases, as well as potentially playing a role in the altered quality of life scores demonstrated following these operative procedures. However, it is unlikely that ghrelin is the major contributor to either early, or late, post-operative weight loss. Other factors, such as early satiety induced by exaggerated post-prandial gut hormone responses, are probably implicated, particularly in longer-term weight loss. Although these data are mainly from non-oesophageal cancer cohorts, the results imply that ghrelin has, at best, a small role in weight loss following upper gastrointestinal cancer surgery.

\subsection{Ghrelin and Cancer Cachexia}

The cancer cachexia-anorexia syndrome is a multifactorial process commonly seen in cancer, involving skeletal muscle and adipose tissue atrophy [97,98]. The issue of weight loss is thus exaggerated in oesophageal cancer patients, who subsequently undergo oesophagectomy, predisposing them to further weight loss $[79,94]$. There are many components to this syndrome, such as a pro-inflammatory response, and physical symptoms of the tumour such as dysphagia [99]. While circulating levels of ghrelin have been shown to be elevated in cancer cachexia, this did not correlate with an increase in appetite, suggesting it was a compensatory response to weight loss [100]. This is consistent with its role in the prevention of muscular atrophy. Ghrelin has been studied in the management of cachexia in murine models [101], due to its ability to release growth hormone, regulate appetite, increase gastric emptying, and its anti-inflammatory properties [5]. Anamorelin, a synthetic GSH-R agonist, had a favourable clinical response profile in advanced cancer patients over 12 weeks of treatment [102]. It has also been effective in increasing food intake and body weight, as well as performance status, in cachexia associated with chronic obstructive pulmonary disease (COPD) [103], and in improving muscle wasting by increasing muscle strength in chronic heart failure-(CHF)-associated cachexia [31]. Ghrelin is a potential targetable factor in the prevention of weight loss and other adverse outcomes associated with cancer, while post-operative suppression of ghrelin may adversely affect patient outcome. All in all, while there have been some promising 
developments and short-term results, there are no long-term reported effects resulting from the therapeutic modulation of ghrelin, nor its incidental post-operative suppression.

\section{Conclusions}

Ghrelin has a multitude of effects, especially within the area of energy homeostasis, appetite regulation, meal initiation, as well as in anticipatory feeding behaviours. It exhibits these actions via complex neurobiological pathways. Although weight loss is inconsistently correlated with ghrelin levels in these post-operative patients, its ties to such powerful neural avenues indicate that it may at least have a role in influencing weight fluctuation through multiple mechanisms. It is clear that acylated ghrelin, and perhaps desacyl ghrelin, have a central role in the hormonal interplay between the gastrointestinal tract and the central nervous system, which does suggest that suppression following upper gastrointestinal operations is likely to have a metabolic effect at both sites. Its intimacy with appetite, a powerful and evocative sensation, lends weight to the concept that ghrelin has an essential role in influencing energy consumption, but the inconsistency of this effect in the post-operative setting and the unexplained mechanism renders its role unclear as of yet.

In conclusion, this fascinating hormone provides an array of stimulating hypotheses and certainly warrants future further investigation with the hope of harnessing the potential of this metabolic player to ultimately improve patient quality of life. However, while the impact of ghrelin suppression with potential anorexigenic sequelae has been examined in the context of oesophageal carcinoma and subsequent surgical interventions, neurobiological consequences of persistently low levels have not been widely explored.

Author Contributions: Conor F. Murphy and Carel W. le Roux wrote the paper together.

Conflicts of Interest: The authors declare no conflict of interest.

\section{References}

1. Kojima, M.; Hosoda, H.; Date, Y.; Nakazato, M.; Matsuo, H.; Kangawa, K. Ghrelin is a growth-hormone-releasing acylated peptide from stomach. Nature 1999, 402, 656-660. [CrossRef] [PubMed]

2. Chen, H.Y.; Trumbauer, M.E.; Chen, A.S.; Weingarth, D.T.; Adams, J.R.; Frazier, E.G.; Shen, Z.; Marsh, D.J.; Feighner, S.D.; Guan, X.M.; et al. Orexigenic action of peripheral ghrelin is mediated by neuropeptide $\mathrm{Y}$ and agouti-related protein. Endocrinology 2004, 145, 2607-2612. [CrossRef] [PubMed]

3. Romero, A.; Kirchner, H.; Heppner, K.; Pfluger, P.T.; Tschop, M.H.; Nogueiras, R. GOAT: The master switch for the ghrelin system? Eur. J. Endocrinol. 2010, 163, 1-8. [CrossRef] [PubMed]

4. Tschop, M.; Smiley, D.L.; Heiman, M.L. Ghrelin induces adiposity in rodents. Nature 2000, 407, $908-913$. [CrossRef] [PubMed]

5. Nakazato, M.; Murakami, N.; Date, Y.; Kojima, M.; Matsuo, H.; Kangawa, K.; Matsukura, S. A role for ghrelin in the central regulation of feeding. Nature 2001, 409, 194-198. [CrossRef] [PubMed]

6. Cowley, M.A.; Smith, R.G.; Diano, S.; Tschöp, M.; Pronchuk, N.; Grove, K.L.; Strasburger, C.J.; Bidlingmaier, M.; Esterman, M.; Heiman, M.L.; et al. The distribution and mechanism of action of ghrelin in the CNS demonstrates a novel hypothalamic circuit regulating energy homeostasis. Neuron 2003, 37, 649-661. [CrossRef]

7. Date, Y.; Murakami, N.; Toshinai, K.; Matsukura, S.; Niijima, A.; Matsuo, H.; Kangawa, K.; Nakazato, M. The role of the gastric afferent vagal nerve in ghrelin-induced feeding and growth hormone secretion in rats. Gastroenterology 2002, 123, 1120-1128. [CrossRef] [PubMed]

8. Date, Y.; Shimbara, T.; Koda, S.; Toshinai, K.; Ida, T.; Murakami, N.; Miyazato, M.; Kokame, K.; Ishizuka, Y.; Ishida, Y.; et al. Peripheral ghrelin transmits orexigenic signals through the noradrenergic pathway from the hindbrain to the hypothalamus. Cell Metab. 2006, 4, 323-331. [CrossRef] [PubMed]

9. Rinaman, L. Ascending projections from the caudal visceral nucleus of the solitary tract to brain regions involved in food intake and energy expenditure. Brain Res. 2010, 1350, 18-34. [CrossRef] [PubMed]

10. Willesen, M.G.; Kristensen, P.; Romer, J. Co-localization of growth hormone secretagogue receptor and NPY mRNA in the arcuate nucleus of the rat. Neuroendocrinology 1999, 70, 306-316. [CrossRef] [PubMed] 
11. Dickson, S.L. Induction of c-fos messenger ribonucleic acid in neuropeptide $\mathrm{Y}$ and growth hormone (GH)-releasing factor neurons in the rat arcuate nucleus following systemic injection of the GH secretagogue, GH-releasing peptide-6. Endocrinology 1997, 138, 771-777. [CrossRef] [PubMed]

12. Currie, P.J.; Khelemsky, R.; Rigsbee, E.M.; Dono, L.M.; Coiro, C.D.; Chapman, C.D.; Hinchcliff, K. Ghrelin is an orexigenic peptide and elicits anxiety-like behaviors following administration into discrete regions of the hypothalamus. Behav. Brain Res. 2012, 226, 96-105. [CrossRef] [PubMed]

13. Olszewski, P.K.; Grace, M.K.; Billington, C.J.; Levine, A.S. Hypothalamic paraventricular injections of ghrelin: Effect on feeding and c-Fos immunoreactivity. Peptides 2003, 24, 919-923. [CrossRef]

14. Merkestein, M.; van Gestel, M.A.; van der Zwaal, E.M.; Brans, M.A.; Luijendijk, M.C.; van Rozen, A.J.; Hendriks, J.; Garner, K.M.; Boender, A.J.; Pandit, R.; et al. GHS-R1a signaling in the DMH and VMH contributes to food anticipatory activity. Int. J. Obes. 2014, 38, 610-618. [CrossRef] [PubMed]

15. van der Lely, A.J.; Tschöp, M.; Heiman, M.L.; Ghigo, E. Biological, physiological, pathophysiological, and pharmacological aspects of ghrelin. Endocr. Rev. 2004, 25, 426-457. [CrossRef] [PubMed]

16. Parent, M.B.; Darling, J.N.; Henderson, Y.O. Remembering to eat: Hippocampal regulation of meal onset. Am. J. Physiol. Regul. Integr. Comp. Physiol. 2014, 306, R701-R713. [CrossRef] [PubMed]

17. Davidson, T.L.; Kanoski, S.E.; Schier, L.A.; Clegg, D.J.; Benoit, S.C. A potential role for the hippocampus in energy intake and body weight regulation. Curr. Opin. Pharmacol. 2007, 7, 613-666. [CrossRef] [PubMed]

18. Mani, B.K.; Walker, A.K.; Lopez Soto, E.J.; Raingo, J.; Lee, C.E.; Perello, M.; Andrews, Z.B.; Zigman, J.M. Neuroanatomical characterization of a growth hormone secretagogue receptor-green fluorescent protein reporter mouse. J. Comp. Neurol. 2014, 522, 3644-3666. [CrossRef] [PubMed]

19. Kanoski, S.E.; Fortin, S.M.; Ricks, K.M.; Grill, H.J. Ghrelin signaling in the ventral hippocampus stimulates learned and motivational aspects of feeding via PI3K-Akt signaling. Biol. Psychiatry 2013, 73, 915-923. [CrossRef] [PubMed]

20. Hsu, T.M.; Hahn, J.D.; Konanur, V.R.; Noble, E.E.; Suarez, A.N.; Thai, J.; Nakamoto, E.M.; Kanoski, S.E. Hippocampus ghrelin signaling mediates appetite through lateral hypothalamic orexin pathways. eLife 2015, 4, e11190. [CrossRef] [PubMed]

21. Yasuda, T.; Masaki, T.; Kakuma, T.; Yoshimatsu, H. Centrally administered ghrelin suppresses sympathetic nerve activity in brown adipose tissue of rats. Neurosci. Lett. 2003, 349, 75-78. [CrossRef]

22. Tsubone, T.; Masaki, T.; Katsuragi, I.; Tanaka, K.; Kakuma, T.; Yoshimatsu, H. Ghrelin regulates adiposity in white adipose tissue and UCP1 mRNA expression in brown adipose tissue in mice. Regul. Pept. 2005, 130, 97-103. [CrossRef] [PubMed]

23. Mano-Otagiri, A.; Iwasaki-Sekino, A.; Nemoto, T.; Ohata, H.; Shuto, Y.; Nakabayashi, H.; Sugihara, H.; Oikawa, S.; Shibasaki, T. Genetic suppression of ghrelin receptors activates brown adipocyte function and decreases fat storage in rats. Regul. Pept. 2010, 160, 81-90. [CrossRef] [PubMed]

24. Mano-Otagiri, A.; Ohata, H.; Iwasaki-Sekino, A.; Nemoto, T.; Shibasaki, T. Ghrelin suppresses noradrenaline release in the brown adipose tissue of rats. J. Endocrinol. 2009, 201, 341-349. [CrossRef] [PubMed]

25. Lin, L.; Saha, P.K.; Ma, X.; Henshaw, I.O.; Shao, L.; Chang, B.H.J.; Buras, E.D.; Tong, Q.; Chan, L.; McGuinness, O.P.; et al. Ablation of ghrelin receptor reduces adiposity and improves insulin sensitivity during aging by regulating fat metabolism in white and brown adipose tissues. Aging Cell 2011, 10, 996-1010. [CrossRef] [PubMed]

26. Filigheddu, N.; Gnocchi, V.F.; Coscia, M.; Cappelli, M.; Porporato, P.E.; Taulli, R.; Traini, S.; Baldanzi, G.; Chianale, F.; Cutrupi, S.; et al. Ghrelin and des-acyl ghrelin promote differentiation and fusion of C2C12 skeletal muscle cells. Mol. Biol. Cell 2007, 18, 986-994. [CrossRef] [PubMed]

27. Porporato, P.E.; Filigheddu, N.; Reano, S.; Ferrara, M.; Angelino, E.; Gnocchi, V.F.; Prodam, F.; Ronchi, G.; Fagoonee, S.; Fornaro, M.; et al. Acylated and unacylated ghrelin impair skeletal muscle atrophy in mice. J. Clin. Investig. 2013, 123, 611-622. [CrossRef] [PubMed]

28. Asakawa, A.; Inui, A.; Kaga, T.; Yuzuriha, H.; Nagata, T.; Ueno, N.; Makino, S.; Fujimiya, M.; Niijima, A.; Fujino, M.A.; et al. Ghrelin is an appetite-stimulatory signal from stomach with structural resemblance to motilin. Gastroenterology 2001, 120, 337-345. [CrossRef] [PubMed]

29. Masuda, Y.; Tanaka, T.; Inomata, N.; Ohnuma, N.; Tanaka, S.; Itoh, Z.; Hosoda, H.; Kojima, M.; Kangawa, K. Ghrelin stimulates gastric acid secretion and motility in rats. Biochem. Biophys. Res. Commun. 2000, 276, 905-908. [CrossRef] [PubMed] 
30. Rizzo, M.; Rizvi, A.; Sudar, E.; Soskic, S.; Obradovic, M.; Montalto, G.; Boutjdir, M.; Mikhailidis, D.; Isenovic, E. A review of the cardiovascular and anti-atherogenic effects of ghrelin. Curr. Pharm. Des. 2013, 19, 4953-4963. [CrossRef] [PubMed]

31. Nagaya, N. Effects of ghrelin administration on left ventricular function, exercise capacity, and muscle wasting in patients with chronic heart failure. Circulation 2004, 110, 3674-3679. [CrossRef] [PubMed]

32. Nagaya, N.; Uematsu, M.; Kojima, M.; Ikeda, Y.; Yoshihara, F.; Shimizu, W.; Hosoda, H.; Hirota, Y.; Ishida, H.; Mori, H.; et al. Chronic administration of ghrelin improves left ventricular dysfunction and attenuates development of cardiac cachexia in rats with heart failure. Circulation 2001, 104, 1430-1435. [CrossRef] [PubMed]

33. Okumura, H.; Nagaya, N.; Enomoto, M.; Nakagawa, E.; Oya, H.; Kangawa, K. Vasodilatory effect of ghrelin, an endogenous peptide from the stomach. J. Cardiovasc. Pharmacol. 2002, 39, 779-783. [CrossRef] [PubMed]

34. Delhanty, P.J.; Neggers, S.J.; van der Lely, A.J. Mechanisms in endocrinology: Ghrelin: The differences between acyl-and des-acyl ghrelin. Eur. J. Endocrinol. 2012, 167, 601-608. [CrossRef] [PubMed]

35. Asakawa, A.; Inui, A.; Fujimiya, M.; Sakamaki, R.; Shinfuku, N.; Ueta, Y.; Meguid, M.M.; Kasuga, M. Stomach regulates energy balance via acylated ghrelin and desacyl ghrelin. Gut 2005, 54, 18-24. [CrossRef] [PubMed]

36. Cummings, D.E. Ghrelin and the short- and long-term regulation of appetite and body weight. Physiol. Behav. 2006, 89, 71-84. [CrossRef] [PubMed]

37. Cummings, D.E. Plasma ghrelin levels and hunger scores in humans initiating meals voluntarily without time- and food-related cues. AJP Endocrinol. Metab. 2004, 287, E297-E304. [CrossRef] [PubMed]

38. Cummings, D.E.; Purnell, J.Q.; Frayo, R.S.; Schmidova, K.; Wisse, B.E.; Weigle, D.S. A preprandial rise in plasma ghrelin levels suggests a role in meal initiation in humans. Diabetes 2001, 50, 1714-1719. [CrossRef] [PubMed]

39. Kojima, M. Ghrelin: Structure and function. Physiol. Rev. 2005, 85, 495-522. [CrossRef] [PubMed]

40. Frecka, J.M.; Mattes, R.D. Possible entrainment of ghrelin to habitual meal patterns in humans. Am. J. Physiol. Gastrointest. Liver Physiol. 2008, 294, G699-G707. [CrossRef] [PubMed]

41. Blum, I.D.; Patterson, Z.; Khazall, R.; Lamont, E.W.; Sleeman, M.W.; Horvath, T.L.; Abizaid, A. Reduced anticipatory locomotor responses to scheduled meals in ghrelin receptor deficient mice. Neuroscience 2009, 164, 351-359. [CrossRef] [PubMed]

42. Tschöp, M.; Wawarta, R.; Riepl, R.L.; Friedrich, S.; Bidlingmaier, M.; Landgraf, R.; Folwaczny, C. Post-prandial decrease of circulating human ghrelin levels. J. Endocrinol. Investig. 2001, 24, RC19-RC21. [CrossRef] [PubMed]

43. Guan, X.-M.; Yu, H.; Palyha, O.C.; McKee, K.K.; Feighner, S.D.; Sirinathsinghji, D.J.S.; Smith, R.G.; van der Ploeg, L.H.T.; Howard, A.D. Distribution of mRNA encoding the growth hormone secretagogue receptor in brain and peripheral tissues. Mol. Brain Res. 1997, 48, 23-29. [CrossRef]

44. Ueberberg, B.; Unger, N.; Saeger, W.; Mann, K.; Petersenn, S. Expression of ghrelin and its receptor in human tissues. Horm. Metab. Res. 2009, 41, 814-821. [CrossRef] [PubMed]

45. Hou, Z.; Miao, Y.; Gao, L.; Pan, H.; Zhu, S. Ghrelin-containing neuron in cerebral cortex and hypothalamus linked with the DVC of brainstem in rat. Regul. Pept. 2006, 134, 126-131. [CrossRef] [PubMed]

46. Korbonits, M.; Bustin, S.A.; Kojima, M.; Jordan, S.; Adams, E.F.; Lowe, D.G.; Kangawa, K.; Grossman, A.B. The Expression of the growth hormone secretagogue receptor ligand ghrelin in normal and abnormal human pituitary and other neuroendocrine tumors 1. J. Clin. Endocrinol. Metab. 2001, 86, 881-887. [CrossRef] [PubMed]

47. Korbonits, M.; Kojima, M.; Kangawa, K.; Grossman, A.B. Presence of ghrelin in normal and adenomatous human pituitary. Endocrine 2001, 14, 101-104. [CrossRef]

48. Zigman, J.M.; Jones, J.E.; Lee, C.E.; Saper, C.B.; Elmquist, J.K. Expression of ghrelin receptor mRNA in the rat and the mouse brain. J. Comp. Neurol. 2006, 494, 528-548. [CrossRef] [PubMed]

49. Diano, S.; Farr, S.A.; Benoit, S.C.; McNay, E.C.; da Silva, I.; Horvath, B.; Gaskin, F.S.; Nonaka, N.; Jaeger, L.B.; Banks, W.A.; et al. Ghrelin controls hippocampal spine synapse density and memory performance. Nat. Neurosci. 2006, 9, 381-388. [CrossRef] [PubMed]

50. Kanoski, S.E.; Hayes, M.R.; Greenwald, H.S.; Fortin, S.M.; Gianessi, C.A.; Gilbert, J.R.; Grill, H.J. Hippocampal leptin signaling reduces food intake and modulates food-related memory processing. Neuropsychopharmacology 2011, 36, 1859-1870. [CrossRef] [PubMed] 
51. Chuang, J.-C.; Zigman, J.M. Ghrelin's roles in stress, mood, and anxiety regulation. Int. J. Pept. 2010, 2010, 1-5. [CrossRef] [PubMed]

52. Spencer, S.J.; Emmerzaal, T.L.; Kozicz, T.; Andrews, Z.B. Ghrelin's role in the hypothalamic-pituitary-adrenal axis stress response: Implications for mood disorders. Biol. Psychiatry 2014, 78, 19-27. [CrossRef] [PubMed]

53. Lutter, M.; Sakata, I.; Osborne-Lawrence, S.; Rovinsky, S.A.; Anderson, J.G.; Jung, S.; Birnbaum, S.; Yanagisawa, M.; Elmquist, J.K.; Nestler, E.J.; et al. The orexigenic hormone ghrelin defends against depressive symptoms of chronic stress. Nat. Neurosci. 2008, 11, 752-753. [CrossRef] [PubMed]

54. Barim, A.O.; Aydin, S.; Colak, R.; Dag, E.; Deniz, O.; Sahin, İ. Ghrelin, paraoxonase and arylesterase levels in depressive patients before and after citalopram treatment. Clin. Biochem. 2009, 42, 1076-1081. [CrossRef] [PubMed]

55. Kurt, E.; Guler, O.; Serteser, M.; Cansel, N.; Ozbulut, O.; Altınbaş, K.; Alataş, G.; Savaş, H.; Gecici, O. The effects of electroconvulsive therapy on ghrelin, leptin and cholesterol levels in patients with mood disorders. Neurosci. Lett. 2007, 426, 49-53. [CrossRef] [PubMed]

56. Panagopoulos, V.; Ralevski, E. The role of ghrelin in addiction: A review. Psychopharmacology 2014, 231, 2725-2740. [CrossRef] [PubMed]

57. Tolle, V.; Bassant, M.H.; Zizzari, P.; Poindessous-Jazat, F.; Tomasetto, C.; Epelbaum, J.; Bluet-Pajot, M.T. Ultradian rhythmicity of ghrelin secretion in relation with gh, feeding behavior, and sleep-wake patterns in rats. Endocrinology 2002, 143, 1353-1361. [CrossRef] [PubMed]

58. Weikel, J.C.; Wichniak, A.; Ising, M.; Brunner, H.; Friess, E.; Held, K.; Mathias, S.; Schmid, D.A.; Uhr, M.; Steiger, A. Ghrelin promotes slow-wave sleep in humans. Am. J. Physiol. Endocrinol. Metab. 2003, 284, E407-E415. [CrossRef] [PubMed]

59. Szentirmai, E.; Hajdu, I.; Obal, F., Jr.; Krueger, J.M. Ghrelin-induced sleep responses in ad libitum fed and food-restricted rats. Brain Res. 2006, 1088, 131-140. [CrossRef] [PubMed]

60. Spencer, S.J.; Xu, L.; Clarke, M.A.; Lemus, M.; Reichenbach, A.; Geenen, B.; Kozicz, T.; Andrews, Z.B. Ghrelin regulates the hypothalamic-pituitary-adrenal axis and restricts anxiety after acute stress. Biol. Psychiatry 2012, 72, 457-465. [CrossRef] [PubMed]

61. Chuang, J.-C.; Perello, M.; Sakata, I.; Osborne-Lawrence, S.; Savitt, J.M.; Lutter, M.; Zigman, J.M. Ghrelin mediates stress-induced food-reward behavior in mice. J. Clin. Investig. 2011, 121, 2684-2692. [CrossRef] [PubMed]

62. Druce, M.R.; Wren, A.M.; Park, A.J.; Milton, J.E.; Patterson, M.; Frost, G.; Ghatei, M.A.; Small, C.; Bloom, S.R. Ghrelin increases food intake in obese as well as lean subjects. Int. J. Obes. 2005, 29, 1130-1136. [CrossRef] [PubMed]

63. Jerlhag, E.; Egecioglu, E.; Dickson, S.L.; Andersson, M.; Svensson, L.; Engel, J.A. Ghrelin stimulates locomotor activity and accumbal dopamine-overflow via central cholinergic systems in mice: Implications for its involvement in brain reward. Addict. Biol. 2006, 11, 45-54. [CrossRef] [PubMed]

64. Jerlhag, E.; Egecioglu, E.; Dickson, S.L.; Douhan, A.; Svensson, L.; Engel, J.A. Ghrelin administration into tegmental areas stimulates locomotor activity and increases extracellular concentration of dopamine in the nucleus accumbens. Addict. Biol. 2007, 12, 6-16. [CrossRef] [PubMed]

65. Skibicka, K.P.; Hansson, C.; Egecioglu, E.; Dickson, S.L. Role of ghrelin in food reward: Impact of ghrelin on sucrose self-administration and mesolimbic dopamine and acetylcholine receptor gene expression. Addict. Biol. 2012, 17, 95-107. [CrossRef] [PubMed]

66. Overduin, J.; Figlewicz, D.P.; Bennett-Jay, J.; Kittleson, S.; Cummings, D.E. Ghrelin increases the motivation to eat, but does not alter food palatability. Am. J. Physiol. Regul. Integr. Comp. Physiol. 2012, 303, R259-R269. [CrossRef] [PubMed]

67. Tong, J.; Mannea, E.; Aimé, P.; Pfluger, P.T.; Yi, C.X.; Castaneda, T.R.; Davis, H.W.; Ren, X.; Pixley, S.; Benoit, S.; et al. Ghrelin enhances olfactory sensitivity and exploratory sniffing in rodents and humans. J. Neurosci. 2011, 31, 5841-5846. [CrossRef] [PubMed]

68. Malik, S.; McGlone, F.; Bedrossian, D.; Dagher, A. Ghrelin modulates brain activity in areas that control appetitive behavior. Cell Metab. 2008, 7, 400-409. [CrossRef] [PubMed]

69. Skibicka, K.P.; Hansson, C.; Alvarez-Crespo, M.; Friberg, P.A.; Dickson, S.L. Ghrelin directly targets the ventral tegmental area to increase food motivation. Neuroscience 2011, 180, 129-137. [CrossRef] [PubMed] 
70. Aghajanzadeh, M.; Safarpour, F.; Koohsari, M.R.; Ghanaei, F.M.; Bodaghi, S.M.; Tozandehgani, H. Functional outcome of gastrointestinal tract and quality of life after esophageal reconstruction of esophagus cancer. Saudi J. Gastroenterol. 2009, 15, 24-28. [CrossRef] [PubMed]

71. Ogden, C.L.; Carroll, M.D.; Kit, B.K.; Flegal, K.M. Prevalence of childhood and adult obesity in the United States, 2011-2012. JAMA 2014, 311, 806-814. [CrossRef] [PubMed]

72. American Cancer Society. Cancer Facts and Figures; American Cancer Society: Atlanta, GA, USA, 2014.

73. Ryan, A.M.; Duong, M.; Healy, L.; Ryan, S.A.; Parekh, N.; Reynolds, J.V.; Power, D.G. Obesity, metabolic syndrome and esophageal adenocarcinoma: Epidemiology, etiology and new targets. Cancer Epidemiol. 2011, 35, 309-319. [CrossRef] [PubMed]

74. Enzinger, P.C.; Mayer, R.J. Esophageal cancer. N. Engl. J. Med. 2003, 349, 2241-2252. [CrossRef] [PubMed]

75. Van Hagen, P.; Hulshof, M.C.C.M.; van Lanschot, J.J.B.; Steyerberg, E.W.; van Berge Henegouwen, M.I.; Wijnhoven, B.P.L.; Richel, D.J.; Nieuwenhuijzen, G.A.P.; Hospers, G.A.P.; Bonenkamp, J.J.; et al. Preoperative Chemoradiotherapy for Esophageal or Junctional Cancer. N. Engl. J. Med. 2012, 366, 2074-2084. [CrossRef] [PubMed]

76. Reynolds, J.V.; Muldoon, C.; Hollywood, D.; Ravi, N.; Rowley, S.; O'Byrne, K.; Kennedy, J.; Murphy, T.J. Long-term outcomes following neoadjuvant chemoradiotherapy for esophageal cancer. Ann. Surg. 2007, 245, 707-716. [CrossRef] [PubMed]

77. Shapiro, J.; van Lanschot, J.J.B.; Hulshof, M.C.C.M.; van Hagen, P.; van Berge Henegouwen, M.I.; Wijnhoven, B.P.L.; van Laarhoven, H.W.M.; Nieuwenhuijzen, G.A.P.; Hospers, G.A.P.; Bonenkamp, J.J. Neoadjuvant chemoradiotherapy plus surgery versus surgery alone for oesophageal or junctional cancer (CROSS): Long-term results of a randomised controlled trial. Lancet Oncol. 2015, 16, 1090-1098. [CrossRef]

78. Martin, L.; Lagergren, P. Long-term weight change after oesophageal cancer surgery. Br. J. Surg. 2009, 96, 1308-1314. [CrossRef] [PubMed]

79. Miyazaki, T.; Tanaka, N.; Hirai, H.; Yokobori, T.; Sano, A.; Sakai, M.; Inose, T.; Sohda, M.; Nakajima, M.; Fukuchi, M.; et al. Ghrelin level and body weight loss after esophagectomy for esophageal cancer. J. Surg. Res. 2012, 176, 74-78. [CrossRef] [PubMed]

80. Doki, Y.; Takachi, K.; Ishikawa, O.; Miyashiro, I.; Sasaki, Y.; Ohigashi, H.; Nakajima, H.; Hosoda, H.; Kangawa, K.; Sasakuma, F.; et al. Ghrelin reduction after esophageal substitution and its correlation to postoperative body weight loss in esophageal cancer patients. Surgery 2006, 139, 797-805. [CrossRef] [PubMed]

81. Beckman, L.M.; Beckman, T.R.; Sibley, S.D.; Thomas, W.; Ikramuddin, S.; Kellogg, T.A.; Ghatei, M.A.; Bloom, S.R.; le Roux, C.W.; Earthman, C.P. Changes in gastrointestinal hormones and leptin after Roux-en-Y gastric bypass surgery. J. Parenter. Enter. Nutr. 2011, 35, 169-180. [CrossRef] [PubMed]

82. Cummings, D.E.; Weigle, D.S.; Frayo, R.S.; Breen, P.A.; Ma, M.K.; Dellinger, E.P.; Purnell, J.Q. Plasma ghrelin levels after diet-induced weight loss or gastric bypass surgery. N. Engl. J. Med. 2002, 346, 1623-1630. [CrossRef] [PubMed]

83. Bose, M.; Machineni, S.; Oliván, B.; Teixeira, J.; McGinty, J.J.; Bawa, B.; Koshy, N.; Colarusso, A.; Laferrere, B. Superior appetite hormone profile after equivalent weight loss by gastric bypass compared to gastric banding. Obesity 2010, 18, 1085-1091. [CrossRef] [PubMed]

84. Uchida, A.; Zechner, J.F.; Mani, B.K.; Park, W.-M.; Aguirre, V.; Zigman, J.M. Altered ghrelin secretion in mice in response to diet-induced obesity and Roux-en-Y gastric bypass. Mol. Metab. 2014, 3, 717-730. [CrossRef] [PubMed]

85. Holdstock, C.; Engstrom, B.E.; Ohrvall, M.; Lind, L.; Sundbom, M.; Karlsson, F.A. Ghrelin and adipose tissue regulatory peptides: Effect of gastric bypass surgery in obese humans. J. Clin. Endocrinol. Metab. 2003, 88, 3177-3183. [CrossRef] [PubMed]

86. Chambers, A.P.; Kirchner, H.; Wilson-Perez, H.E.; Willency, J.A.; Hale, J.E.; Gaylinn, B.D.; Thorner, M.O.; Pfluger, P.T.; Gutierrez, J.A.; Tschop, M.H.; et al. The effects of vertical sleeve gastrectomy in rodents are ghrelin independent. Gastroenterology 2013, 144, 50.e5-52.e5. [CrossRef] [PubMed]

87. Banasch, M.; Bulut, K.; Hagemann, D.; Schrader, H.; Holst, J.J.; Schmidt, W.E.; Meier, J.J. Glucagon-like peptide 2 inhibits ghrelin secretion in humans. Regul. Pept. 2006, 137, 173-178. [CrossRef] [PubMed]

88. Hagemann, D.; Holst, J.J.; Gethmann, A.; Banasch, M.; Schmidt, W.E.; Meier, J.J. Glucagon-like peptide 1 (GLP-1) suppresses ghrelin levels in humans via increased insulin secretion. Regul. Pept. 2007, 143, 64-68. [CrossRef] [PubMed] 
89. Elliott, J.A.; Docherty, N.G.; Eckhardt, H.G.; Doyle, S.L.; Guinan, E.M.; Ravi, N.; Reynolds, J.V.; le Roux, C.W. Weight loss, satiety, and the postprandial gut hormone response after esophagectomy: A prospective study. Ann. Surg. 2016. [CrossRef] [PubMed]

90. Saad, M.F.; Bernaba, B.; Hwu, C.M.; Jinagouda, S.; Fahmi, S.; Kogosov, E.; Boyadijan, R. Insulin regulates plasma ghrelin concentration. J. Clin. Endocrinol. Metab. 2002, 87, 3997-4000. [CrossRef] [PubMed]

91. Wang, H.T.; Lu, Q.C.; Wang, Q.; Wang, R.C.; Zhang, Y.; Chen, H.L.; Zhao, H.; Qian, H.X. Role of the duodenum in regulation of plasma ghrelin levels and body mass index after subtotal gastrectomy. World J. Gastroenterol. 2008, 14, 2425-2429. [CrossRef] [PubMed]

92. Tremaroli, V.; Karlsson, F.; Werling, M.; Ståhlman, M.; Kovatcheva-Datchary, P.; Olbers, T.; Fändriks, L.; le Roux, C.W.; Nielsen, J.; Bäckhed, F. Roux-en-Y gastric bypass and vertical banded gastroplasty induce long-term changes on the human gut microbiome contributing to fat mass regulation. Cell Metab. 2015, 22, 228-238. [CrossRef] [PubMed]

93. Clarke, G.; Stilling, R.M.; Kennedy, P.J.; Stanton, C.; Cryan, J.F.; Dinan, T.G. Minireview: Gut microbiota: The neglected endocrine organ. Mol. Endocrinol. 2014, 28, 1221-1238. [CrossRef] [PubMed]

94. Koizumi, M.; Hosoya, Y.; Dezaki, K.; Yada, T.; Hosoda, H.; Kangawa, K.; Nagai, H.; Lefor, A.T.; Sata, N.; Yasuda, Y. Postoperative weight loss does not resolve after esophagectomy despite normal serum ghrelin levels. Ann. Thorac. Surg. 2011, 91, 1032-1037. [CrossRef] [PubMed]

95. Yamamoto, K.; Takiguchi, S.; Miyata, H.; Adachi, S.; Hiura, Y.; Yamasaki, M.; Nakajima, K.; Fujiwara, Y.; Mori, M.; Kangawa, K.; et al. Randomized phase II study of clinical effects of ghrelin after esophagectomy with gastric tube reconstruction. Surgery 2010, 148, 31-38. [CrossRef] [PubMed]

96. Franz, M.J.; VanWormer, J.J.; Crain, A.L.; Boucher, J.L.; Histon, T.; Caplan, W.; Bowman, J.D.; Pronk, N.P. Weight-loss outcomes: A systematic review and meta-analysis of weight-loss clinical trials with a minimum 1-year follow-up. J. Am. Diet. Assoc. 2007, 107, 1755-1767. [CrossRef] [PubMed]

97. Amitani, M.; Asakawa, A.; Amitani, H.; Inui, A. Control of food intake and muscle wasting in cachexia. Int. J. Biochem. Cell Biol. 2013, 45, 2179-2185. [CrossRef] [PubMed]

98. Donohoe, C.L.; Ryan, A.M.; Reynolds, J.V. Cancer cachexia: Mechanisms and clinical implications. Gastroenterol. Res. Pract. 2011, 2011, 1-13. [CrossRef] [PubMed]

99. Ezeoke, C.C.; Morley, J.E. Pathophysiology of anorexia in the cancer cachexia syndrome. J. Cachexia Sarcopenia Muscle 2015, 6, 287-302. [CrossRef] [PubMed]

100. Garcia, J.M.; Garcia-Touza, M.; Hijazi, R.A.; Taffet, G.; Epner, D.; Mann, D.; Smith, R.G.; Cunningham, G.R.; Marcelli, M. Active ghrelin levels and active to total ghrelin ratio in cancer-induced cachexia. J. Clin. Endocrinol. Metab. 2005, 90, 2920-2926. [CrossRef] [PubMed]

101. DeBoer, M.D.; Zhu, X.X.; Levasseur, P.; Meguid, M.M.; Suzuki, S.; Inui, A.; Taylor, J.E.; Halem, H.A.; Dong, J.Z.; Datta, R. Ghrelin treatment causes increased food intake and retention of lean body mass in a rat model of cancer cachexia. Endocrinology 2007, 148, 3004-3012. [CrossRef] [PubMed]

102. Garcia, J.M.; Boccia, R.V.; Graham, C.D.; Yan, Y.; Duus, E.M.; Allen, S.; Friend, J. Anamorelin for patients with cancer cachexia: An integrated analysis of two phase 2, randomised, placebo-controlled, double-blind trials. Lancet Oncol. 2015, 16, 108-116. [CrossRef]

103. Nagaya, N.; Itoh, T.; Murakami, S.; Oya, H.; Uematsu, M.; Miyatake, K.; Kangawa, K. Treatment of cachexia with ghrelin in patients with COPD. Chest 2005, 128, 1187-1193. [CrossRef] [PubMed]

(C) 2016 by the authors; licensee MDPI, Basel, Switzerland. This article is an open access article distributed under the terms and conditions of the Creative Commons Attribution (CC-BY) license (http://creativecommons.org/licenses/by/4.0/). 